\title{
ČÁRY MÁRY: ČÁRY! NÁSTRAHY VIZUALIZACÍ SÍTÍ NEJEN V HORIZONTÁLNÍCH DĚJINÁCH UMĚNÍ
}

\author{
TOMÁŠ KOLICH \\ Ústav pro dějiny umění Filozofické fakulty Univerzity Karlovy \\ t.j.kolich@gmail.com
}

\begin{abstract}
Abracadabra: lines! Pitfalls of network visualizations not only in the horizontal art history

The article analyses the symbolism on network visualizations with a focus on the so-called horizontal art history. It shows that this symbolism can obscure the proper application and assessment of network models. The horizontal art history is particularly prone to this because it is based on a metaphorical juxtaposition (with Western "vertical" art history) which is similar to the juxtaposition that cocreates the network symbolism - (visual) juxtaposition of networks and hierarchies. The article demonstrates effects of this symbolism with the examples of the network diagram from the exhibition Inventing Abstraction, 1910-1925 (MOMA, New York, 2012) and the uncritical acceptance of this diagram by some proponents of the horizontal art history.

Keywords: network visualizations - horizontal art history - Piotr Piotrowski - Inventing Abstraction, 1910-1925 - Alfred H. Barr - Abstract art - metaphors in science - visual juxtapositions
\end{abstract}

\section{Prolog: 0 čem tento příspěvek je a není}

Tento př́íspěvek je součástí rozsáhlejšího výzkumu, který se soustředuje na symbolismus obrazů sítí (datových vizualizací, vědeckých popularizací apod.), a to jak ve vědeckém prostředí, tak každodenní kultuře. Cílem tohoto výzkumu je určit, jak tento symbolismus vzniká, jak se šírí, jaké významy konotuje a jaký má dopad. ${ }^{1}$ Horizontální dějiny umění jsou jednou z několika oblastí, kde je možné efekty takovéhoto symbolismu sledovat (viz slovo „nejen“v názvu příspěvku). Záměrem tohoto příspěvku není zpochybnit horizontální dějiny umění jako celek, ani žádná jiná „destabilizace“ obdobných rozměrů, nýbrž upozornit na problémy, které zde kvưli zmíněnému symbolismu vznikají. Příspěvek nerozporuje prínos sítových modelů v jiných oborech, včetně digitálních dějin umění (avšak nevylučuje, že se v nich symbolismus sítí může uplatňovat obdobným způsobem).

1 V současnosti je v tisku můj př́spěvek Iconography of transformation. Network images from the art-historical perspective soustředující se na vytváření tohoto symbolismu skrze juxtapozice sítových a hierarchických struktur, který bude publikován ve sdruženém sborníku 7th and 8th International Congress of Art History Students in Zagreb. 
Pokud v tomto př́íspěvku vznáším kritická tvrzení, která se zdají více všeobjímající, týkají se jen a právě (vesměs rétorického) inkorporování sítí do horizontálních dějin umění. To proto, že se mi při mém průzkumu podařilo dohledat pouze problematické příklady tohoto inkorporování, přičemž vyhledávání probíhalo cíleně pomocí relevantních bibliografií i náhodně skrze zadávání neutrálních klíčových slov (např. „Piotrowski“, „network“ atd.) do databází jako Google Scholar a Google Books, primárně v angličtině. Rozšířenost takovéhoto problematického inkorporování dokládají mimo jiné odlišné národnosti mnou citovaných autorů, bez ohledu na skutečnost, že (přirozeně) publikují anglicky.

Protože sítě jsou v současných dějinách umění (alespoň těch horizontálních) vnímány převážně pozitivně, nebudu tento text „vybalancovávat“ př́iklady kvalitního uplatnění sítových modelů. ${ }^{2}$ Zároveň nebudu sítě a jejich funkce speciálně definovat, nebot: 1) mnou citovaní autoři to většinou také nedělají, 2) to, co míním sítí, je dle mého soudu patrné z textu a obrazových příloh, 3) tím nechci napínat limitovaný rozsah př́íspěvku, z něhož jsem už dosti „ukrojil“ tímto prologem.

\section{Úvodem: Sítě jsou všude}

Modely sítí se staly oblíbenou metodou v řadě disciplín, jak v přírodních vědách, tak i humanitních. S příchodem nového milénia se objevila řada (populárně-naučných) publikací zvěstujících budoucnost, v níž se sítě stanou univerzální strukturou veškerenstva. Přestože byl takovýto nekritický sítový entuziasmus kritizován již od svých začátků, ${ }^{3}$ je stále velmi čilý, částečně proto, že sítě nejsou vnímány (a používány) pouze jako badatelský nástroj, nýbrž jako vlivná a účinná metafora. Metafora přechodu od starých, strnulých, hierarchických zř́zení k novým, dynamickým a propojeným.

Tento symbolický efekt sítí se projevuje i v dějinách umění. Sítě slouží nejen jako užitečná metoda pro zpracování dat v rámci digitálních dějin umění, ale i jako metafora uplatňovaná těmi historiky umění, kteří požadují přehodnocení „starých př́ístupư“.

Platí to konkrétně pro výzkum avantgardy první poloviny 20. století. Jako jeden z prvních navrhl vnímat avantgardu jako sít Hubert van den Berg v roce $2006 .{ }^{4}$ Dnes tato výzva zaznívá především v takzvaných horizontálních dějinách umění, jak to popisuje například Michał Wenderski ve své práci příznačně nazvané Cultural Mobility in the Interwar Avant-Garde Art Network: Poland, Belgium and the Netherlands: „For more than a decade, since the so-called "spatial turn", the avant-garde network has gradually come

2 Pro aktuální přehled způsobů využití analýzy sítí v dějinách umění viz např. Matthew $\mathrm{D}$. Lincoln, Tangled Metaphors: Network Thinking and Network Analysis in the History of Art, in: Kathryn Brown (ed.), The Routledge Companion to Digital Humanities and Art History, New York 2020, s. 73-87. Dále speciální číslo časopisu Artl@s Bulletin věnované tématu Visualizing Networks: Approaches to Network Analysis in Art History, zejména Miriam Kienle, Between Nodes and Edges: Possibilities and Limits of Network Analysis in Art History, Artl@s Bulletin VI, č. 3, 2017, s. 4-22.

3 Pro výstižnou kritiku přehnaného sítového entuziasmu viz Grahame F. Thompson, Is all the world a complex network?, Economy and Society XXXIII, 2004, s. 411-424, cit. s. 424.

4 Hubert van den Berg, Mapping Old Traces of the New. Towards a Historical Topography of Early Twentieth-Century Avant-Garde(s), Arcadia XLI, 2006, s. 331-349. 
to be mapped by various scholars who have analysed and described its nodes (artistic formations, galleries, magazines, exhibitions, etc.) and the connecting lines between them. "5

Jedním z hlavních šiřitelů sítového symbolismu jsou vizualizace, jejichž zjednodušující jazyk uzlů a spojů unifikuje různorodé typy interakcí a smazává rozdíly mezi sítěmi, které jsou materiální, virtuální, sociální či mechanické. Každá standardní vizualizace sítě tudíž není jen zobrazením konkrétního setu dat, ale i abstraktním symbolem zmíněných idejí propojenosti či nestálosti. Coby symbol odvádí pozornost od samotného procesu sítového modelování a možných chyb. Prezentace těchto vizualizací se tak někdy podobá kouzelnickému vystoupení - jsme uchváceni sugestivními obrazy propojených bodů, ale způsob vzniku je nám zatajen. Čáry máry: čáry!

V této práci se zaměřím na využívání vizualizací sítí coby metafory (nejen) v horizontálních dějinách umění, a především na juxtapozice sítových a hierarchických struktur, které jsou vytvářeny jak vizuálně, tak rétoricky. Mým cílem je ukázat, že tyto juxtapozice mohou být použity k propagaci sítí či horizontálních dějin umění, ale i k maskování jejich vad a $\mathrm{k}$ (ne)vědomému matení znesnadňujícímu zhodnotit potenciální přínos takovéhoto propojení. Tuto skutečnost budu demonstrovat zejména na př́kladu vizualizace sítě Z výstavy Inventing Abstraction, 1910-1925 pořádané v roce 2012 v Museum of Modern Art v New Yorku.

\section{Juxtapozice v teorii sítí a horizontálních dějinách umění}

Historie sítových modelů poskytuje několik příkladů vizuálních juxtapozic hierarchických a sítových struktur, z nichž některé jsou dnes již ikonické.

Příkladem je ilustrace, kterou použil Paul Baran ve svém návrhu na komunikační systém v roce $1962 .{ }^{6}$ Coby zaměstnanec RAND Corporation byl Baran pověřen úkolem, aby navrhl pro americkou armádu komunikační systém, který by přežil útok jaderných zbraní.

Na totožném vzoru uzlů prezentuje Baran tři možné typy propojení: centralizovaný (všechny uzly napojeny na jeden centrální rozbočovač), decentralizovaný (uzly napojeny na periferní rozbočovače a následně na centrální) a distribuovaný (uzly napojeny na „nejbližšího souseda“). Distribuovaný typ, který Baran doporučil, vedl o pár let později k vytvoření systému ARPANET, který dal vzniknout internetu.

Baranova ilustrace je reprodukována v pracích o teorii sítí dodnes. Je to významný historický mezník, ale svou roli patrně sehrává i její vizuální přitažlivost. Je abstraktní uzly ani spoje nejsou pojmenované -, a proto ji lze snadno využít pro odlišné účely. Coby vizuální metaforu ji vytěžil například americký politický komentátor Glenn Beck na konferenci Ignition Media v roce 2011. Na své notoricky známé tabuli Baranovu juxtapozici prezentoval coby ilustraci proměny naší společnosti - posilování individua, eliminování „prostředníků “ atd. Skutečnost, že politický komentátor může v roce 2011 použít diagram z technického článku z šedesátých let téměř beze změn (Beck pouze odstranil názvy typů) dokládá jeho symbolický potenciál.

5 Michał Wenderski, Cultural Mobility in the Interwar Avant-Garde Art Network: Poland, Belgium and the Netherlands, New York 2018, s. 1.

6 Paul Baran, On distributed communications networks, Santa Monica 1962. 
Baranův článek obsahoval i diagram nazvaný „An Array of Stations“, který zachycoval podstatu jím navrhované distribuované sítě jako přepojování paketů. Jak poznamenala Anna Munster, tento diagram, který působí více genericky, je dnes mnohem méně reprodukovaný. ${ }^{7}$ Důvodem patrně je, že distribuovaná sít zde není v juxtapozici s hierarchickou a nevyužívá „zdání“ topografie uzlů - stanice jsou organizované v jednoduchém čtvercovém rastru. Baranův první diagram i přes svou abstraktnost využívá rozložení uzlů připomínající reálný prostor a je to právě toto „zdáni““ topografie, které nejsilněji propojuje sítě a horizontální dějiny umění na metaforické úrovni.

Horizontální dějiny umění jsou totiž už od svého uvedení Piotrem Piotrowským samy založené na dvojici metafor zrcadlící tuto juxtapozici. ${ }^{8}$ Piotrowski se vymezuje vůči dějinám umění, které označuje za „vertikální“, čímž míní západní způsob operující s konceptem center a pasivně přejímajících periférií. Namísto něj navrhuje horizontální dějiny umění, které by narušily tento stávající jednosměrný vztah, byly by vědomě lokalizované a transnacionální: „A horizontal art history should begin with the deconstruction of vertical art history, that is, the history of Western art."

Piotrowského pojmy „vertikálni““ a „horizontálni“ jsou tedy rovněž metaforou přechodu od starých (západních), strnulých, hierarchických (operujících s centry a periferiemi) dějin umění k novým (globálním), dynamickým a propojeným (transnacionálním).

Piotrowski sám sítě přímo nezmiňuje, ale připravuje pro ně půdu. V současnosti jsou sítě do horizontálních dějin umění inkorporovány skrze zmíněné symbolické juxtapozice s hierarchiemi, jak to potvrzuje např́iklad rétorika Michała Wenderského: "in the case of transnational minorities such as the avant-garde network, there is no place for hierarchy. "10 V těchto zjednodušujících metaforách je snadné ignorovat fakt, že i sítové struktury mají většinou určitou vnitřní hierarchii. A cílem sítového modelování je určení a analýza právě této vnitřní hierarchie.

V rámci horizontálně-sítového přístupu dochází i ke dvojímu standardu při posuzování sebereflexe avantgardistů. Zatímco Piotrowski zdůrazňoval, že vertikální perspektiva není výtvorem avantgardy, nýbrž pozdějších dějin umění, ${ }^{11}$ van den Berg a další se dopouštějí přesně takovéhoto (dle mého soudu ahistorického) interpretování a sítové myšlení hledají přímo ve výrocích dobových umělců. ${ }^{12}$

7 Anna Munster, An Aesthesia of Networks: Conjunctive Experience in Art and Technology, Cambridge 2013, s. 27.

8 Piotr Piotrowski, On the Spatial Turn, or Horizontal Art History, Uméní LXI, 2008, s. 378-383. Následně publikováno jako Piotr Piotrowski, Toward a Horizontal History of the European AvantGarde, in: Sascha Bru - Jan Baetens - Benedikt Hjartarson - Peter Nicholls - Tania Ørum - Hubert Berg (eds), Europa! Europa? The Avant-Garde, Modernism and the Fate of a Continent, Berlin 2009, s. 49-58. Zde cituji z této verze.

9 Ibidem, s. 54.

10 Wenderski (pozn. 5), s. 7.

11 Piotrowski (pozn. 8), s. 51.

12 Van den Berg (pozn. 4), s. 33; Malte Hagener, Mushrooms, Ant Paths and Tactics. The Topography of the European Film Avant-Garde, in: Per Bäckström - Benedikt Hjartarson (eds), Decentring the Avant-Garde, London 2014, s. 145-168, cit. s. 161. 


\section{Abstraktní umění jako produkt sítového myšlení}

Jedním z nejvíce veřejných využití sítí v dějinách umění byla výstava Inventing Abstraction, 1910-1925 (dále jen Inventing Abstraction) pořádaná v Museum of Modern Art (dále jen MoMA) v New Yorku v roce 2012. Výstava představila rozměrnou vizualizaci sítě zobrazující komunikaci abstraktních umělcủ, která nebyla prezentována jako pouhé ozvláštnění typu časových os, ${ }^{13}$ ale jako manifestace kurátorského př́stupu.

V katalogu výstavy bylo zřetelnè uvedeno: "abstraction was not the inspiration of a solitary genius but the product of a network thinking." ${ }^{\prime 4}$ Argumentace ovšem sestávala pouze z několika letmých odkazů na sociologické publikace tvrdící, ${ }^{15}$ že inovace vychází ze sociální interakce, a samotná vizualizace se ukázala jako velmi problematická.

Byla vytvořena jako vědomá reakce na slavný diagram Alfreda $\mathrm{H}$. Barra použitý na obalu katalogu výstavy Cubism and Abstract Art v roce 1936 v téže instituci. ${ }^{16}$ Podobnost je patrná ve zvolené barevnosti a fontu. Kurátoři zde vytvořili kalkulovanou juxtapozici, která je ideologická i vizuální.

Barr ve svém diagramu operuje téměř výhradně s uměleckými směry a jmenovitě zmiňuje pouze sedm umělců. Vektory vlivu směřují vždy jen jedním směrem a nepřipouštějí vzájemnou inspiraci mezi jednotlivými -ismy ani v př́padě, že jsou současné. ${ }^{17}$

Sit Inventing abstraction je navržena tak, aby působila zcela opačně. Sestává pouze z individuálních umělců a hustá sít neorientovaných spojů naznačuje vzájemný vliv a kontinuální komunikaci. Toto přesvědčování o výhodách sítového modelu skrze juxtapozici s hierarchickou strukturou ovšem není doprovázeno přesvědčivými poznatky.

Umělci (uzly) zbarvení červeně představují rozbočovače (anglicky hubs). Podle legendy diagramu (vpravo dole) jsou takto označeni ti, kteří mají dvacet čtyři a více spojů. ${ }^{18}$ Legenda ani katalog ovšem neuvádějí, proč byl zvolen tento počet.

Rozložení uzlů je rovněž záhadné. Kdyby se jednalo o tzv. force-directed vizualizaci, nejvíce propojené uzly by byly uprostřed a ty nejméně na krajích. Sít Inventing abstraction je však distribuována patrně podle jiného principu - geografické mapy Evropy a částečně USA. Italští umělci jsou na jihu, ruští na východě atd. Přirozeně, centrální část (zhruba

13 Webová stránka výstavy obsahuje interaktivní verzi diagramu, kde je možné rozkliknout spoje jednotlivých umělců (konkrétní čísla, která uvádím v textu, jsem získal ručním spočítáním). Ještě před výstavou bylo plánováno, že online verze bude specifikovat povahu jednotlivých spojů. Robin Cembalest, MoMA Makes a Facebook for Abstractionists, Artnews, http://www.artnews.com/2012/10/02 /momaabstractionfaceboo/, vyhledáno 27. 5. 2019.

14 Glenn D. Lowry, Foreword, in: Leah Dickerman (ed.), Inventing Abstraction, 1910-1925. How a Radical Idea Changed Modern Art, New York 2013, s. 7-8, cit. s. 7.

15 Leah Dickerman, Inventing Abstraction in: Leah Dickerman (ed.), Inventing Abstraction, 1910-1925. How a Radical Idea Changed Modern Art, New York 2013, s. 12-39.

16 Ibidem, s. 21.

17 Barrův diagram měl přibližit nedávný a komplikovaný vznik abstrakce široké veřejnosti, odtud jeho zjednodušující povaha. Pro detailní analýzu diagramu viz Edward Tufte, Beautiful Evidence, Cheshire 2006, s. 20. Pro historii vzniku diagramu viz Glenn D. Lowry, Abstraction in 1936 Barr's Diagrams, in: Leah Dickerman (ed.), Inventing Abstraction, 1910-1925. How a Radical Idea Changed Modern Art, New York 2013, s. 358-363.

18 The Museum of Modern Art, Network Diagram, Inventing Abstraction, 1910-1925, https://www.moma .org/interactives/exhibitions/2012/inventingabstraction/MoMA_InventingAbstraction_Network _Diagram.pdf, vyhledáno 27.5.2019. 
v místech Francie a Německa) je nejhustší. Jakákoli indicie objasňující rozvržení sítě opět chybí jak v diagramu, tak v katalogu.

Samotné rozbočovače jsou také problematické. Leah Dickerman, hlavní autorka výstavy, označila za klíčové spojovatele („key connectors“) několik již dobře známých jmen jako Apollinaire (28 spojů), Marinetti (26 spojů), Kandinsky (25 spojů) a Tzara (24 spojů). ${ }^{19}$ Opomíjí ale například Soniu Delaunay-Terk, která má 27 spojů. Navíc zahrnuje mezi klíčové spojovatele i Alfreda Stieglitze, který je v diagramu zobrazen jako červený rozbočovač, přestože má pouze 19 spojů! To vyvolává otázku, zdali kurátoři diagram skutečně vytěžili k získání nových poznatků, nebo se jen snažili potvrdit si předem ustanovené domněnky.

Zásadní je absence jakéhokoli popisu o typu informací, které touto sítí domněle proudí. ${ }^{20}$ Mluvíme zde o intenzivní diskusi, nebo o výměně pohlednic? Komunikovali umělci opakovaně, nebo pouze jednou? Jednalo se o vzájemnou výměnu informací, nebo jednostranný monolog? Sloužili zmínění klíčoví spojovatelé jako mediátoři šíření informací, nebo vedli zcela oddělené dialogy? Bez popisu typu informací a zobrazení jejich toku $\mathrm{v}$ rámci sítě tyto otázky nelze zodpovědět. ${ }^{21}$

\section{Kolmé metafory a príičné řezy}

I kdyby sít Inventing abstraction napravila tyto výtky, zůstává zde jeden fundamentální problém, který je typický pro vizualizace sítí obecně - upřednostňování prostoru oproti času. Proměňovala se tato sít ve zkoumaném období 1910-1925? Našli bychom během první světové války stejné klíčové spojovatele jako v polovině dvacátých let? Nejenže sít Inventing abstraction chronologii vynechává; prostor aktivně zdůrazňuje skrze zmíněnou geografii Evropy a USA. Negeografická force-directed vizualizace by byla stále primárně prostorová, ale ne tak dominantně.

Ve vymezení se vůči Barrovu diagramu, který prezentuje hierarchii stylů v přesných časových vrstvách (časové osy po stranách a data vzniku -ismů), je tento kontrast ještě zřetelnější. Juxtapozice hierarchií a sítí, kterou kurátoři MoMA prezentují, implikuje i juxtapozici časového a prostorového podání.

Antagonismus času a prostoru se projevuje v horizontálních dějinách umění obecně. Piotrowski sám přirozeně zdůrazňuje prostorové vnímání dějin umění (svůj původní článek nazval „On the Spatial Turn"), ale vưči časovosti se výslovně nevymezuje. ${ }^{22}$ Ně-

19 Dickerman (pozn. 15.), s. 21-22.

20 Legenda pouze oznamuje: "vectors connect individuals whose acquaintance with one another during these years could be documented" The Museum of Modern Art (pozn. 18).

21 Diagram navrhl tým Paula Ingrama, specialisty na analýzu sítí z Columbia Business School na základě dat poskytnutých kurátory. Ingramovo jméno bylo během propagace často zmiňováno na rozdíl od skutečnosti, že jeho původní diagram byl upraven grafickým týmem MoMA ve snaze najít "an appropriate form”, přičemž finální verze je jedna z deseti zkoušených. The Museum of Modern Art, Behind the Scenes: The Making of Inventing Abstraction's Artist Network Diagram, Inventing Abstraction, 1910-1925, http://www.moma.org/interactives/exhibitions/2012/inventingabstraction/?page =conversations, vyhledáno 27. 5. 2019.

22 V případě knihy Art since 1900 nekritizuje chronologické uspořádání, ale nedostatečné inkorporování kritické geografie. Piotrowski, Toward a Horizontal History of the European Avant-Garde (pozn. 8), s. 50 . 
kteří historici umění ovšem interpretují jeho výzvu k dekonstrukci vertikálních dějin umění právě jako výzvu k upřednostnění topografie před chronologií. Např́íklad Foteini Vlachou soudí: „Piotrowski made a convincing case for an art history that would be, horizontal' instead of vertical and hierarchical, focusing on space (...) instead of time. "23 Jiní tuto dichotomii přímo aplikovali do univerzitní výuky. ${ }^{24}$

Piotrowským zvolené termíny „vertikální“ a „horizontální“ se samy k takovémuto uchopení nabízejí. Požadavek dekonstrukce hierarchických západních dějin umění mohl vyargumentovat bez nich. Rozhodl se však kritizovaný i proponovaný způsob dějin umění vykreslit jako dva vzájemně kolmé př́istupy. Ideově i geometricky neslučitelné. Namísto omezení se na přesné definice použil dvojici metafor, která napomáhá šíření jeho konceptu, ale i jeho možné dezinterpretaci.

Pro účel demystifikování juxtapozic hierarchických a sítových struktur však toto zkreslení může být ilustrující. Pokud bychom vertikální dějiny umění skutečně interpretovali jako časové, a horizontální coby prostorové, zjistíme, že jejich konfrontování je vlastně nesmyslné. Jedná se pouze o dva základní způsoby nahlížení jednoho a téhož umělecko-historického vývoje.

Už George Kubler v knize The Shape of Time popsal toto dvojí nahlížení, když do své definice vývoje forem zahrnul jak stromově-časový, tak i sítově-prostorový „náhled“, jejichž vyjevení záleží na typu řezu, který zvolíme: „In cross section let us say that it shows a network, a mesh, or a cluster of subordinate traits; and in long section that it has a fiber-like structure of temporal stages (...)."25

Vizuálně by takovéto řešení mohlo vypadat například jako modely vývoje ptáků Maxe Fürbringera z konce 19. století: fylogenetický strom, který z bočního náhledu ukazuje tradiční větvení v čase a v horizontálním řezu příbuznost jednotlivých řádů a jejich robustnost. Jedna struktura tak může být hierarchií i sítí zároveň. ${ }^{26}$

23 Foteini Vlachou, Notes from the Periphery: History and Methods, Visual Resources XXXV, 2019, s. $193-199$, cit. s. 195 .

24 Např. Allison Leigh pojala svůj seminář inspirovaný horizontálními dějinami umění na University of Louisiana jako analýzu (nejen výtvarného) umění vzniklého v roce 1820 na širokém geografickém území od Španělska po Rusko. Sama ale připustila neefektivnost takovéhoto přístupu. Allison Leigh, An Experiment in Horizontal Art History: Critiquing Modernist Geographies (konferenční př́íspěvek), Theorizing the Geography of East-Central European Art Conference, Poznaň 2018, https://www .youtube.com/watch?v=T8uPZHOkYcg, vyhledáno 27. 5. 2019.

25 George Kubler, The Shape of Time. Remarks on the History of Things, New Haven-London 2008, s. 33.

26 O transformování Barrova diagramu do podoby sítě se pokusila Yanan Sun. Její sít je ovšem jen zdánlivá. Sun nahradila jednotlivé položky třemi typy uzlů, odstranila směr vektorů a časové osy, rozložení uzlů však zůstalo identické s Barrovým (vertikálně chronologické). Skutečná multimodální sít by vyžadovala „zploštit“ chronologii tak, jako je to u Inventing Abstraction, a použít např. force-directed rozložení. Sun zmiňuje i sít v MoMA, ale zcela nekriticky ji považuje za reprezentativní př́íklad toho, jak mohou dějiny umění těžit $z$ analytických nástrojů sociologie. Yanan Sun, From Diagram to Network. A Multi-mode Network Approach to Analyze Diagrams of Art History, in: Akiyo Nadamoto - Adam Jatowt - Adam Wierzbicki - Jochen L. Leidner (eds), Social Informatics. SocInfo 2013, Berlin-Heidelberg 2014, s. 100-109, zvl. s. 103. 


\section{Závěrem: Sebepotvrzující mýty}

Problém tkví v tom, že Piotrowského projekt horizontálních dějin umění je, stejně jako sítě, silně metaforický. Piotrowski si toho sám byl vědom, když jím kýžený posun od "fields" $\mathrm{k}$,actors" popsal jako "metaphorical shift“. ${ }^{27}$ Př́značné v tomto směru je, že mnozí z proponentů sítových modelů či horizontálních dějin umění často zmiňují pojem "rizom" - další akademicky známou, ale v praxi nepoužitelnou metaforu, kterou navrhli Gilles Deleuze a Félix Guattari coby nahrazení stromových struktur organizace ve své knize Tisíc plošin v roce 1980. Juxtapozice se opakují.

$\mathrm{V}$ př́padě vrstvení těchto metafor nás nemůže překvapit, že konkrétní praktické aplikace sítových modelů a jejich funkčnost nejsou v kontextu horizontálních dějin umění adekvátně analyzovány. ${ }^{28}$ Napríklad Michał Wenderski o síti Inventing abstraction pouze nekriticky prohlašuje: „This diagram is a very interesting visualisation of contemporary approaches to research on artistic networks which concentrate on representatives, nodes, and the relationships between them. " ${ }^{29}$ Jiný príklad poskytuje Pam Meecham, který sít Inventing abstraction napojuje prímo na van den Berga a zmíněnou dezinterpretaci konceptu Piotrowského: "And the move from linear to the horizontal can be seen in exhibitions that use expansive horizontal charts visualizing wider global connectivity. MoMA's 2012 exhibition Inventing Abstraction 1910-1925 moves away from Alfred Barr's influential (...) diagram (...) which (the horizontal placing of dates notwithstanding) has a vertical trajectory. ${ }^{30}$

Přestože jsou sítě a jejich vizualizace nezpochybnitelně užitečným nástrojem digitálních dějin umění, jejich propojení s těmi horizontálními se zatím odehrává pouze na zmíněné metaforické úrovni, která je rétoricky lákavá, ale v konkrétních realizacích dělá spiše medvědí službu. Brání jak úspěšné aplikaci, tak i jejímu kritickému zhodnocení. Diagram Inventing abstraction není ani kvalitním příkladem sítového modelování, ani horizontálních dějin umění a je jen přínačné, že ani s jednou z těchto metod není v katalogu výstavy jakkoli pracováno. Jak ale vidno z př́kladů Wenderského, Meechama a obecně nedostatku kritických hlasů, symbolická povaha sítových vizualizací v kombinaci s metaforickým jazykem horizontálních dějin umění tuto skutečnost zastiňuje.

Filozof vědy Max Black kdysi výstižně napsal, že každá věda pravděpodobně začíná metaforou a končí algebrou. Metafory (které nazýval archetypy) s sebou ale vždy nesou nebezpečí: „Of course, there is an ever-present and serious risk that the archetype will be used metaphysically, so that its consequences will be permanently insulated from empirical disproof. The more persuasive the archetype, the greater the danger of it becoming a self-certifying myth. ${ }^{31}$

27 Piotrowski (pozn. 8), s. 52; Piotrowského patrně inspirovala actor-network theory (ANT) proponovaná Brunem Latourem (za upozornění na tuto možnou spojitost děkuji Marii Rakušanové), která je rovněž metaforická už v samotném základu: „ANT is a change of metaphors to describe essences: instead of surfaces one gets filaments" Bruno Latour: On actor-network theory: A few clarifications, Soziale Welt XLVII, 1996, s. 369-381, cit. s. 370.

28 Sít Inventing abstraction měla jen několik negativních kritik ze strany historiků umění. Tu nejdetailnější poskytuje Miriam Kienle, která také shrnuje dosavadní negativní a pozitivní komentáře. Kienle (pozn. 2), s. 13-15.

29 Wenderski (pozn. 5), s. 1-2.

30 Pam Meecham, Contemporary Displays of Modern Art, in: Pam Meecham (ed.), A Companion to Modern Art, Hoboken 2018, s. 145-161, cit. s. 151-152.

31 Max Black, Models and metaphors. Studies in language and philosophy, New York 1962, s. 242. 
Pokud sítě v horizontálních dějinách umění nepřekonají úroveň symbolických juxtapozic a kolmých metafor, mylně považovaných za jasně definované termíny, hrozí jim přesně tento osud sebepotvrzujících mýtů, které nepřinášejí nové výsledky, ale nelze je ani adekvátně kritizovat, a které se vznášejí donekonečna kdesi v pomyslném akademickém limbu.

\section{SUMMARY}

\section{Abracadabra: lines! Pitfalls of network visualizations not only in the horizontal art history}

The research of networks has become a familiar method in various disciplines including art history. Networks are used not only as an analytical tool, but also as symbol - symbolizing a shift from old hierarchical establishments into new dynamic types of organization. Illustrations and visualizations are a key feature of this symbolism and its proliferation.

Undesirable effects of this network symbolism are noticeable in the horizontal art history, where it sometimes obscures the incorrect or insufficient application of network models.

The connection of network visualizations and the horizontal art history is motivated mainly by the fact that both fields are based on metaphorical juxtapositions.

In the case of networks, it is a juxtaposition of systems organized as hierarchy and as network. History of the network research provides visual examples of this juxtaposition e. g. the Paul Baran's diagram of communication systems from 1962. This kind of juxtaposition was also strongly present in the network diagram from the exhibition Inventing Abstraction, 1910-1925 held in 2012 at the MOMA, New York.

The MOMA diagram was intentionally inspired by and contrasted with the Alfred $\mathrm{H}$. Barr's hierarchical diagram from his Cubism and Abstract Art exhibition in 1936. This juxtaposition presented the "seeming" advantages of the network model (focus on individuals instead of groups, interconnectivity instead of one-way influence etc.) as self-evident; however, it also hid the numerous faults and limited epistemic value of this network diagram.

The horizontal art history is based on a similar metaphorical juxtaposition. As defined by Piotr Piotrowski, the horizontal art history demands a deconstruction of the Western "vertical" art history which is founded on the notion of centres and peripheries.

However, Piotrowski's proposal has been misinterpreted by some art historians as a demand for the replacement of chronology with topography - this is exactly what network visualizations do if they are used simplistically. The misrepresentation of Piotrowski's concept combined with the simplistic understanding of network visualizations (like in the case of Inventing Abstraction) leads to erroneous claims about the nature of the early avant-garde. 


\section{VÝBĚROVÁ BIBLIOGRAFIE}

Paul Baran, On distributed communications networks, Santa Monica 1962.

Hubert van den Berg, Mapping Old Traces of the New. Towards a Historical Topography of Early Twentieth-Century Avant-Garde(s), Arcadia XLI, 2006, s. 331-349.

Max Black, Models and metaphors. Studies in language and philosophy, New York 1962.

Robin Cembalest, MoMA Makes a Facebook for Abstractionists, Artnews, http://www.artnews .com/2012/10/02/momaabstractionfaceboo/, vyhledáno 27. 5. 2019.

Leah Dickerman, Inventing Abstraction in: Leah Dickerman (ed.), Inventing Abstraction, 1910-1925. How a Radical Idea Changed Modern Art, New York 2013, s. 12-39.

Malte Hagener, Mushrooms, Ant Paths and Tactics. The Topography of the European Film Avant-Garde, in: Per Bäckström - Benedikt Hjartarson (eds), Decentring the Avant-Garde, London 2014, s. 145-168.

Miriam Kienle, Between Nodes and Edges: Possibilities and Limits of Network Analysis in Art History, Artl@s Bulletin VI, č. 3, 2017, s. 4-22.

George Kubler, The Shape of Time. Remarks on the History of Things, New Haven-London 2008.

Bruno Latour: On actor-network theory: A few clarifications, Soziale Welt XLVII, 1996, s. 369-381.

Allison Leigh, An Experiment in Horizontal Art History: Critiquing Modernist Geographies (konferenční př́spěvek), Theorizing the Geography of East-Central European Art Conference, Poznaň 2018, https://www.youtube.com/watch?v=T8uPZHOkYcg, vyhledáno 27. 5. 2019.

Matthew D. Lincoln, Tangled Metaphors: Network Thinking and Network Analysis in the History of Art, in: Kathryn Brown (ed.), The Routledge Companion to Digital Humanities and Art History, New York 2020, s. 73-87.

Glenn D. Lowry, Abstraction in 1936 Barr's Diagrams, in: Leah Dickerman (ed.), Inventing Abstraction, 1910-1925. How a Radical Idea Changed Modern Art, New York 2013, s. 358-363.

Glenn D. Lowry, Foreword, in: Leah Dickerman (ed.), Inventing Abstraction, 1910-1925. How a Radical Idea Changed Modern Art, New York 2013, s. 7-8.

Pam Meecham, Contemporary Displays of Modern Art, in: Pam Meecham (ed.), A Companion to Modern Art, Hoboken 2018, s. 145-161.

Anna Munster, An Aesthesia of Networks: Conjunctive Experience in Art and Technology, Cambridge 2013.

The Museum of Modern Art, Behind the Scenes: The Making of Inventing Abstraction's Artist Network Diagram, Inventing Abstraction, 1910-1925, http://www.moma.org/interactives/exhibitions/2012 /inventingabstraction/?page=conversations, vyhledáno 27. 5. 2019.

The Museum of Modern Art, Network Diagram, Inventing Abstraction, 1910-1925, https://www.moma .org/interactives/exhibitions/2012/inventingabstraction/MoMA_InventingAbstraction_Network _Diagram.pdf, vyhledáno 27. 5. 2019.

Piotr Piotrowski, Toward a Horizontal History of the European Avant-Garde, in: Sascha Bru - Jan Baetens - Benedikt Hjartarson - Peter Nicholls - Tania Ørum - Hubert Berg (eds), Europa! Europa? The Avant-Garde, Modernism and the Fate of a Continent, Berlin 2009, s. 49-58.

Yanan Sun, From Diagram to Network. A Multi-mode Network Approach to Analyze Diagrams of Art History, in: Akiyo Nadamoto - Adam Jatowt - Adam Wierzbicki - Jochen L. Leidner (eds), Social Informatics. SocInfo 2013, Berlin-Heidelberg 2014, s. 100-109

Grahame F. Thompson, Is all the world a complex network?, Economy and Society XXXIII, 2004, s. 411424.

Edward Tufte, Beautiful Evidence, Cheshire 2006.

Foteini Vlachou, Notes from the Periphery: History and Methods, Visual Resources XXXV, 2019, s. 193199.

Michał Wenderski, Cultural Mobility in the Interwar Avant-Garde Art Network: Poland, Belgium and the Netherlands, New York 2018. 


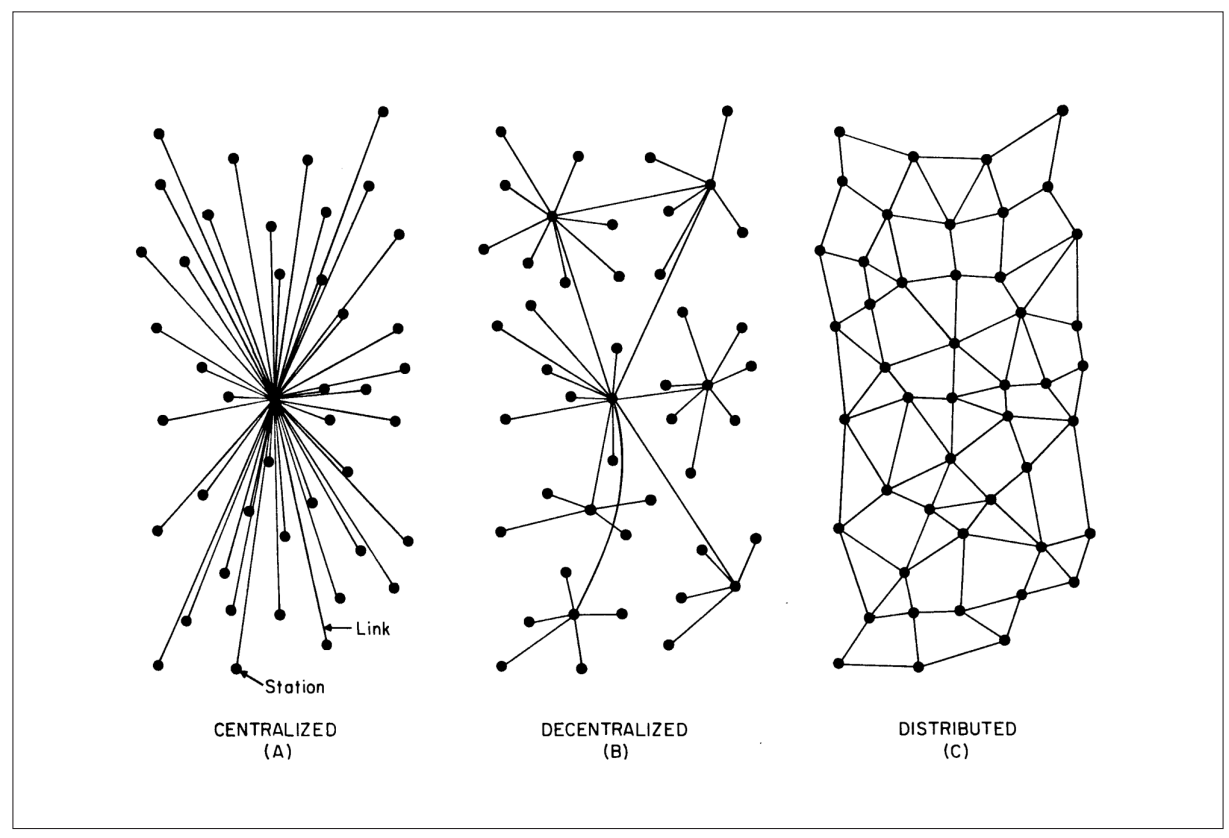

Obrázek 1. Paul Baran, Centralized, Decentralized and Distributed Networks, 1962. Reprodukce ze stati Paula Barana, On distributed communications networks, Santa Monica 1962

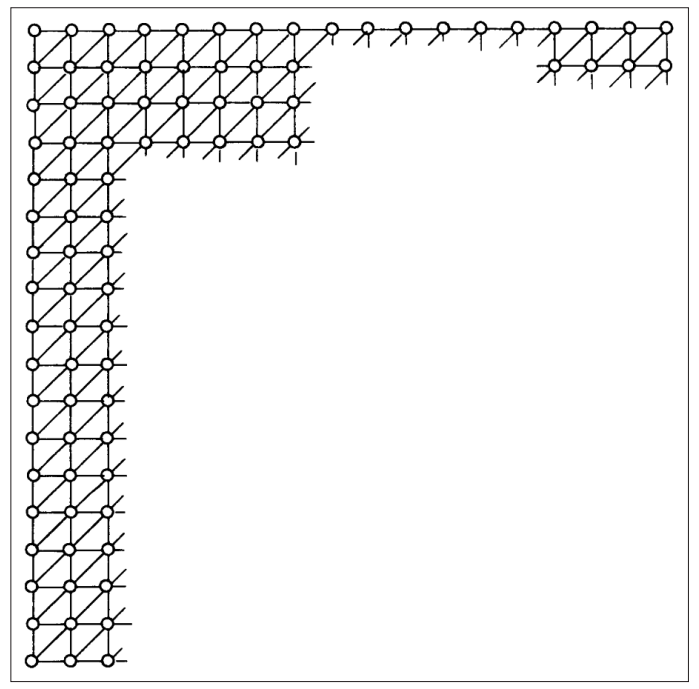

Obrázek 2. Paul Baran, An Array of Stations, 1962. Reprodukce ze stati Paula Barana, On distributed communications networks, Santa Monica 1962 


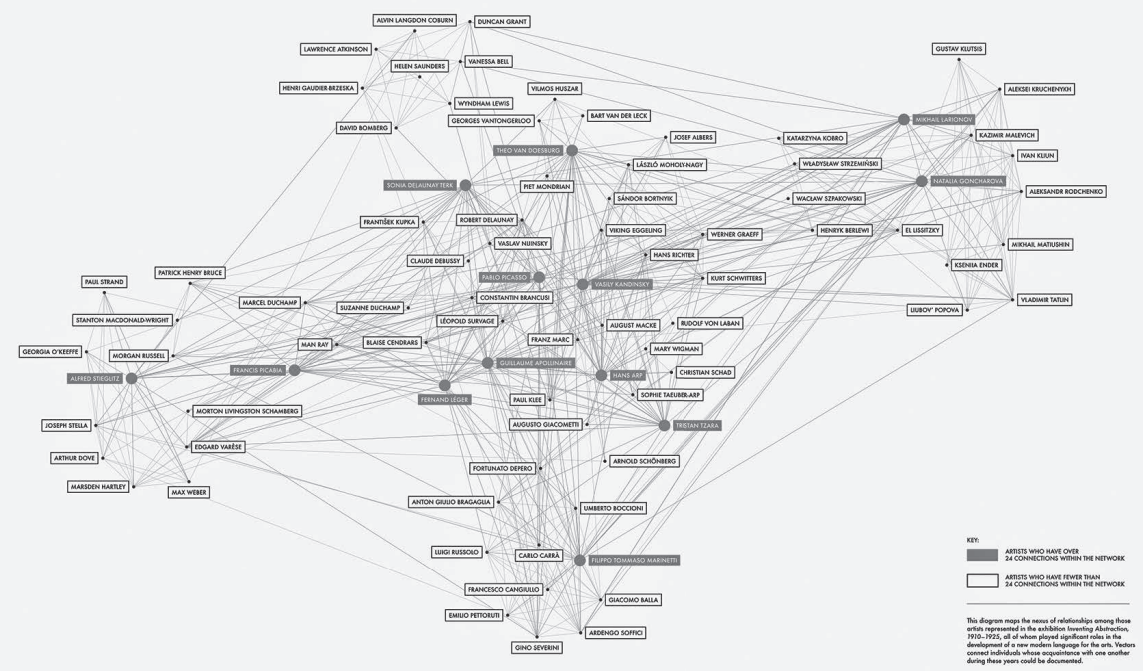

Obrázek 3. Vizualizace sítě z výstavy Inventing Abstraction, 1910-1925, v The Museum of Modern Art v New Yorku (kurátorky Leah Dickerman a Masha Chlenova), 2012. Reprodukce z webových stránek The Museum of Modern Art, http://www.moma.org

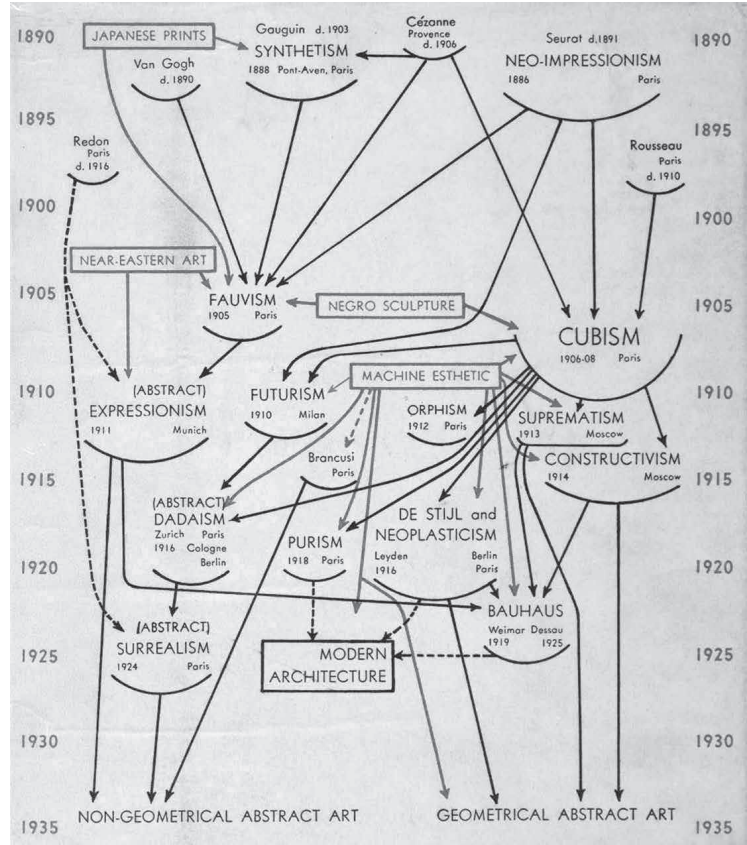

CUBISM AND ABSTRACT ART
Obrázek 4. Alfred H. Barr, Jr., Diagram z výstavy Cubism and Abstract Art, 1936. Reprodukce z obálky knihy Alfreda H. Barra, Jr., Cubism and Abstract Art, New York 1936 


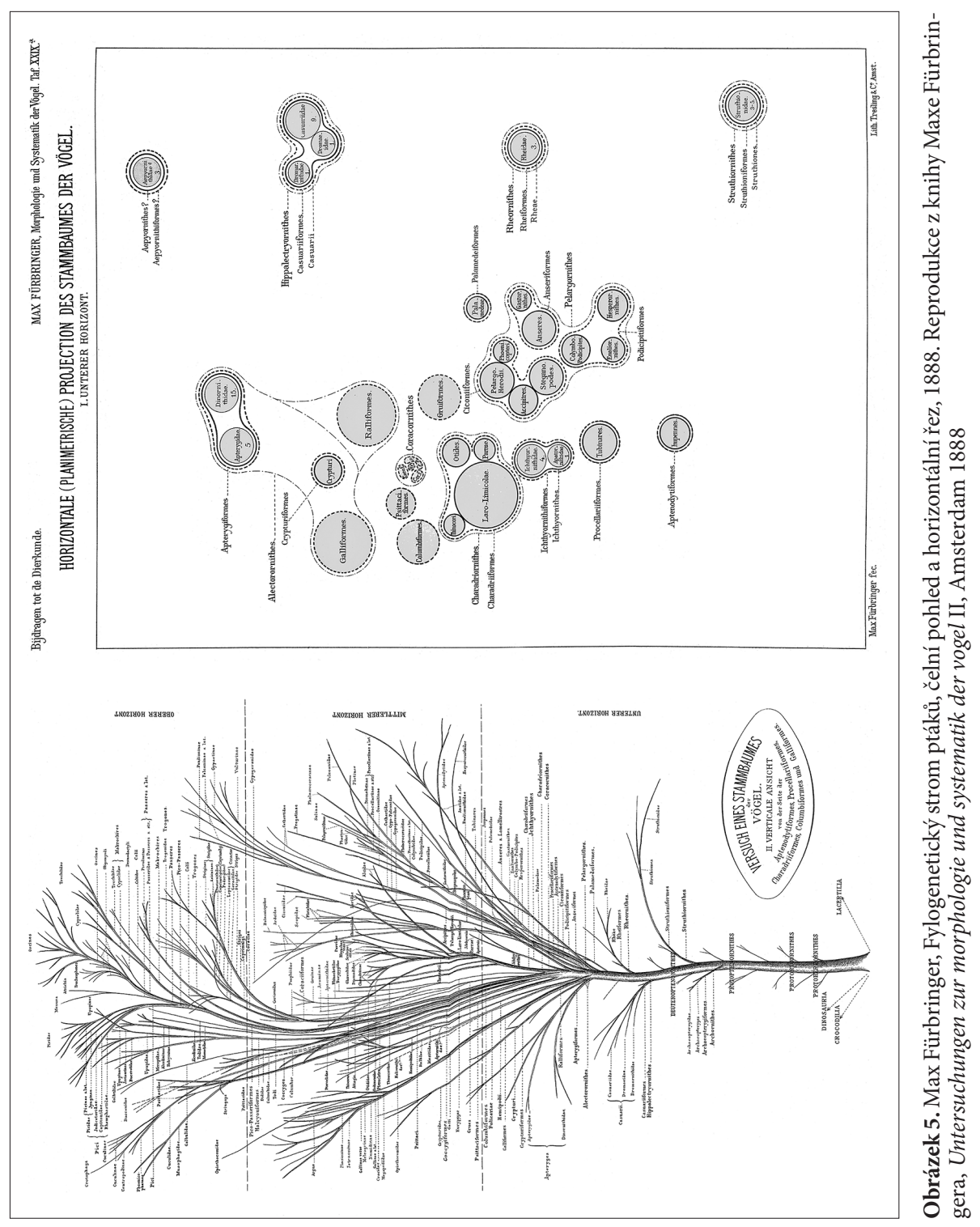

